\title{
The Reproductive Biology of Pagellus bogaraveo, a New Candidate Species for Aquaculture
}

\author{
Valeria Micale $^{*}, 1$, Lucrezia Genovese ${ }^{1}$, Maria Cristina Guerrera ${ }^{2}$, Rosaria Laurà ${ }^{2}$, \\ Giulia Maricchiolo ${ }^{1}$ and Ugo Muglia ${ }^{2}$ \\ ${ }^{I}$ Institute for Marine Coastal Environment, National Research Council (IAMC-CNR), Messina, Italy \\ ${ }^{2}$ Department of Morphology, Biochemistry, Physiology and Animal Production, Faculty of Veterinary Medicine, \\ University of Messina, Italy
}

\begin{abstract}
A brief review of investigations carried out at IAMC-CNR Messina on the reproductive biology of farmed blackspot sea bream Pagellus bogaraveo, a new candidate species for aquaculture, is presented. Different aspects of sexuality, including hermaphroditism, gametogenesis, spermatozoal ultrastructure, maturity staging, seasonal development of gonads, and spawning in captivity, were studied. Protandrous hermaphroditism appeared to be the prevalent sexual pattern, although a high incidence of gonochorism occurred. Males were most abundant in smaller size classes and reached sexual maturity at $28.0 \mathrm{~cm}$, while females predominated in the larger size classes and reached maturity at $29.5 \mathrm{~cm}$. The reproductive season lasted from February until April, as in the natural environment. Spontaneous spawning in tank occurred occasionally, whereas approximately $50 \%$ of females produced eggs upon stripping. The remaining $50 \%$ failed to ovulate, or even to achieve oocyte maturation, indicating an impaired reproductive functionality. A high incidence of oocyte atresia was also recorded. Males produced a small quantity of highly viscous milt, containing only $3 \%$ motile spermatozoa. The spermatozoon of P.bogaraveo has an ovoid head, a midpiece containing only one mitochondrion, and a $50.64 \pm 4.82 \mu \mathrm{m}$ long flagellum, inserted perpendicularly and eccentrically into the nucleus.
\end{abstract}

Keywords: Pagellus bogaraveo, reproduction, hermaphroditism, fish culture.

\section{INTRODUCTION}

Reproduction is one of those aspects of fish biology that are most critical to farming. In fact, many fish exhibit reproductive dysfunctions when reared in captivity, probably because of captivity-induced stress and/or the lack of appropriate "natural" spawning environment [1]. Females are usually more seriously affected by environmental stressors, failing to undergo final oocyte maturation (FOM), ovulation and spawning, or even vitellogenesis, while male dysfunctions may result in low quantity and/or quality of milt. For this reason, studying the reproductive biology of captive populations, including seasonal changes in gonad development, maturation and spawning, is of paramount importance for a full development of farming of new species.

The blackspot sea bream Pagellus bogaraveo (Brünnich, 1768), a demersal fish belonging to the family Sparidae (Perciformes, Teleostei), common in western Mediterranean and eastern Atlantic, may represent an alternative to traditionally cultured marine fish, such as seabass and seabreams, because of high market value and decreasing catches [2]. The first trials on the farming of this hermaphroditic species $[3,4]$ were carried out at IAMC-CNR Messina, Italy (former Istituto Sperimentale Talassografico CNR), and highlighted its suitability for captivity. Great effort has been devoted since then by our research group to investigate different

*Address correspondence to this author at the IAMC-CNR, Spianata S. Raineri, 86 - 98122, Messina, Italy; Tel: +39090669003; Fax: +39090669007; E-mail: valeria.micale@iamc.cnr.it aspects of the reproductive biology of farmed P.bogaraveo, which resulted in the first report on the sexuality of this species in captivity [5]. The present paper is intended as a summary of knowledge acquired during a ten year-study conducted, by means of histological examination of gonads and/or gonadal biopsies, on wild-born specimens reared in tanks at the facilities of IAMC Messina, and will include the following issues: hermaphroditism and sex structure, oogenesis, spermatogenesis and the spermatozoon, maturity staging of ovaries and testes, seasonal development of gonads, and spawning in captivity.

\section{HERMAPHRODITISM AND SEX STRUCTURE}

Histological analysis of gonadal samples from a captive population aged $1+$ to 4 years $(n=224)$ revealed four gonad types in P.bogaraveo, namely, I) ovotestes with a functional testis and quiescent ovary (Mf), II) ovotestes with a functional ovary and regressed testis ( $\mathbf{m F}$ ), III) ovaries with no male tissue (F), and IV) ovotestes with quiescent ovary and testis (mf), together with undifferentiated gonads (und) found in juveniles $\leq 22.0 \mathrm{~cm}$. The size- and age-frequency distributions of gonad types are reported in Figs. (1 and 2), respectively.

Females $(\mathbf{F}+\mathbf{m F})$ occurred in all size classes and represented the absolute majority of the population. Males (Mf) were most frequently found between 21.0 and $25.0 \mathrm{~cm}$, less frequently between 25.0 and $29.0 \mathrm{~cm}$ and they were totally lacking beyond this size. On the other hand, secondary females $\mathbf{m F}$ were found in a very small percentage until 


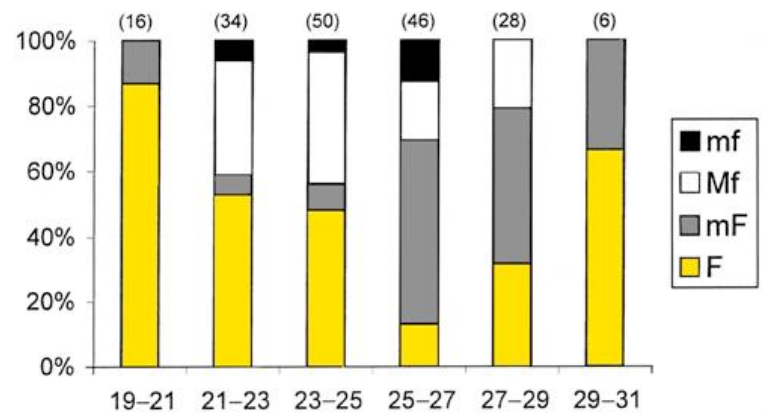

Fig. (1). Size-frequency distribution of gonad types in farmed $P$. bogaraveo. Size classes are reported in $\mathrm{cm}$. The number of examined specimens is reported in brackets.

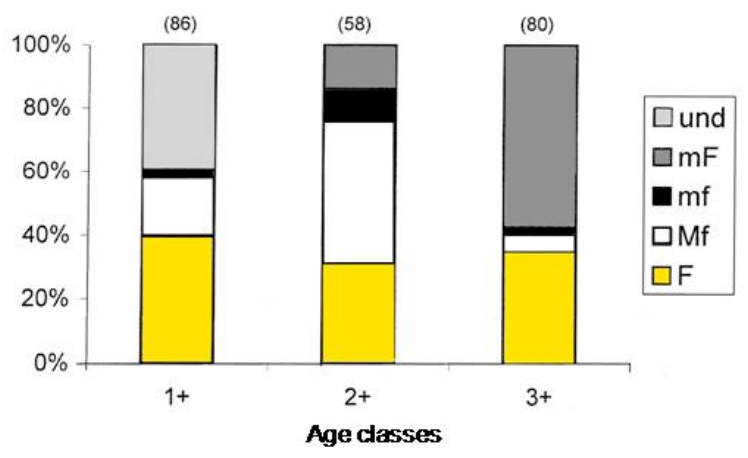

Fig. (2). Age-frequency distribution of gonad types in farmed $P$. bogaraveo. Age classes are reported in years. The number of examined specimens is reported in brackets.
$25.0 \mathrm{~cm}$, while they largely predominated in the higher size cla-sses. The same trend was observed taking into consideration fish age: gonochoric females $\mathbf{F}$ were found in a more or less constant proportion in all age classes, secondary females $\mathbf{m F}$ were lacking in $1+$ class, occurred in a small proportion in $2+$ class $(13.8 \%)$ and predominated in $3+$ class $(57.5 \%)$. On the other hand, functional males Mf were most abundant in $2+$ class $(44.8 \%)$ and strongly decreased in $3+$ class $(5.0 \%)$. Intersexual individuals $\mathbf{m f}$ were found in all age classes in the size range $21.0-26.9 \mathrm{~cm}$. Overall, the captive population consisted of $25 \%$ functional males Mf, 29 $\%$ secondary females $\mathbf{m F}, 41 \%$ gonochoric females $\mathbf{F}$ and $5 \%$ transitionals mf. Thus, protandrous hermaphroditism appeared to be the prevalent sexual pattern, although a high incidence of gonochorism occurred as well. The overall sex ratio of males to females was $1: 2.8$, with females representing the great majority of sexually mature specimens.

\section{OOGENESIS}

Oogenesis, that is the process by which oogonia transform into fertilizable eggs, occurs in P.bogaraveo through ten developmental stages, which are described by means of their microscopical features in Table 1. Following oogonial proliferation by mitosis, the initiation of meiosis is indicated by nuclear changes occurring in the oocyte. Subsequently, a prolonged period of meiotic arrest occurs, during which accumulation of lipid and protein yolk occurs in the ooplasm (vitellogenesis), with a considerable increase in oocyte size. Distinct changes in both the nucleus and

Table 1. Histological Description of Oocyte Development in Pagellus bogaraveo

\begin{tabular}{|c|c|c|c|}
\hline & Oogenic Stage & Size $(\mu \mathrm{m})$ & Histological Description \\
\hline \multirow{9}{*}{ 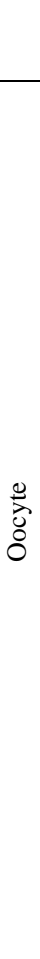 } & Oogonia & $7-15$ & $\begin{array}{l}\text { Large nucleus with one large, eosinophilic nucleolus. They may occur isolated or gathered in small } \\
\text { nests in the epithelium of the ovarian folds. }\end{array}$ \\
\hline & Chromatin nucleolus & $15-25$ & $\begin{array}{l}\text { Slightly basophilic cytoplasm. Large nucleus with chromatin filaments and many strongly basophilic } \\
\text { nucleoli, one of which larger, in a central or sub-central position. }\end{array}$ \\
\hline & Early perinucleolus & $25-45$ & $\begin{array}{l}\text { Strongly basophilic cytoplasm. Large nucleus with one or two larger and several smaller peripheral } \\
\text { basophilic nucleoli. At the end of this stage, the flattened nuclei of the spindle-shaped follicle cells } \\
\text { become visible. }\end{array}$ \\
\hline & Late perinucleolus & $50-90$ & $\begin{array}{l}\text { Granulous, slightly basophilic cytoplasm. Acidophilic nucleus, with 10-20 peripheral nucleoli. } \\
\text { Towards the end of this stage, few, small, lipid droplets appear scattered in the cytoplasm. }\end{array}$ \\
\hline & Cortical alveolus I & $80-240$ & $\begin{array}{l}\text { Slightly basophilic cytoplasm. Convoluted nucleus with many flattened nucleoli inside nuclear } \\
\text { envelope invaginations. } \\
\text { Cortical alveoli appear in the cytoplasm. A thin, acidophilic zona radiata (ZR) is visible. }\end{array}$ \\
\hline & Cortical alveolus II & $200-400$ & $\begin{array}{l}\text { Slightly acidophilic nucleus. Large }(15-25 \mu \mathrm{m}) \text { cortical alveoli spread throughout the cytoplasm. } \\
\text { Lipid droplets adjacent to the nucleus. Thickened, finely striated ZR }(2.5 \mu \mathrm{m}) \text {. Granulosa and theca } \\
\text { layers become visible. }\end{array}$ \\
\hline & Yolk granule I & $300-500$ & $\begin{array}{l}\text { Protein yolk granules appear in the outer cytoplasmic cortex, interspersed between cortical alveoli. } \\
\text { Lipid droplets enlarge }(5-30 \mu \mathrm{m}) \text {. ZR thickened }(5-7.5 \mu \mathrm{m}) \text { and tripartite. Granulosa cells become } \\
\text { prominent and cuboidal. }\end{array}$ \\
\hline & Yolk granule II & $500-700$ & $\begin{array}{c}\text { Protein yolk granules }(5-20 \mu \mathrm{m}) \text { filling cytoplasm. Cortical alveoli form a ring in the outer cortex, } \\
\text { separated from the ZR by a narrow zone of slightly basophilic cytoplasm. Lipid droplets }(25-75 \mu \mathrm{m}) \\
\text { packed around the nucleus. The tripartite ZR is further thickened }(7.5-12.5 \mu \mathrm{m}) \text { Prominent } \\
\text { intercellular spaces between the cuboidal granulosa cells. }\end{array}$ \\
\hline & $\begin{array}{l}\text { Final Oocyte Maturation } \\
\qquad(\text { FOM) }\end{array}$ & $700-1100$ & $\begin{array}{l}\text { At the beginning of this stage, peripheral migration of the nucleus occurs. Protein yolk granules and } \\
\text { lipid droplets begin to coalesce. Subsequently, dissolution of the nucleus (germinal vesicle } \\
\text { breakdown) occurs, and oocyte volume significantly increases because of hydration. Thin, stretched } \\
\text { follicle layers break at ovulation. }\end{array}$ \\
\hline & Hyaline egg & $1200 \pm 0.02$ & Yolk as an homogeneous and translucent mass. One single oil droplet measuring $0.26 \pm 0.001 \mathrm{~mm}$. \\
\hline
\end{tabular}


ooplasm occur upon resumption of meiosis, which marks the beginning of oocyte maturation. These events include migration and breakdown of the nucleus, now called germinal vesicle, fusion of protein yolk granules leading to ooplasm translucence, coalescence of lipid droplets to form a single oil droplet, and a significant increase in the oocyte size by hydration. In captivity, a large number (46\%) of the largest vitellogenic oocytes present in the maturing ovaries fail to undergo final maturation and become atretic. At the onset of atresia, the ZR becomes convoluted and starts to break up in many points. The follicle granulosa cells become hypertrophic, invade the oocyte through the broken down ZR and start to digest the yolky contents. As atresia proceeds, the ZR appears strongly convoluted, collapses in many fragments towards the centre of oocyte and eventually disappears.

\section{SPERMOTOGENESIS AND THE SPERMATO- ZOON}

Spermatogenesis, that is the process by which spermatogonia transform into sperm, occurs in P.bogaraveo through six developmental stages, which are described by means of their microscopical features in Table 2. Spermatogenesis occurs in a fairly synchronous way within spermatocysts outlined by Sertoli cells, in the seminiferous lobules. The newly formed spermatozoa are subsequently released into the lobular lumen, continuing to the main sperm duct, from which they are released during spermiation.

The morphological and ultrastructural features of the mature spermatozoon were studied by scanning and transmission electron microscopy [6]. The spermatozoon of P.bogaraveo has an acrosome-less, ovoid head, a short midpiece containing one mitochondrion, and a flagellum $(50.64 \pm 4.82 \mu \mathrm{m})$ inserted perpendicularly and eccentrically with respect to the nucleus (Fig. 3). A deep nuclear invagination, called the nuclear fossa, houses the centriolar complex, which consists of the proximal and distal centrioles, arranged perpendicularly to each other. A peculiar, ultrastructural feature of the spermatozoon of P.bogaraveo is a satellite nuclear notch, originating from the nuclear fossa, which appears to be unique to the family Sparidae, and may be of systematic importance. Unlike the majority of the sparid species, which show such structure at the level of the proximal centriole, the nuclear notch in P.bogaraveo is located at the level of the distal centriole.

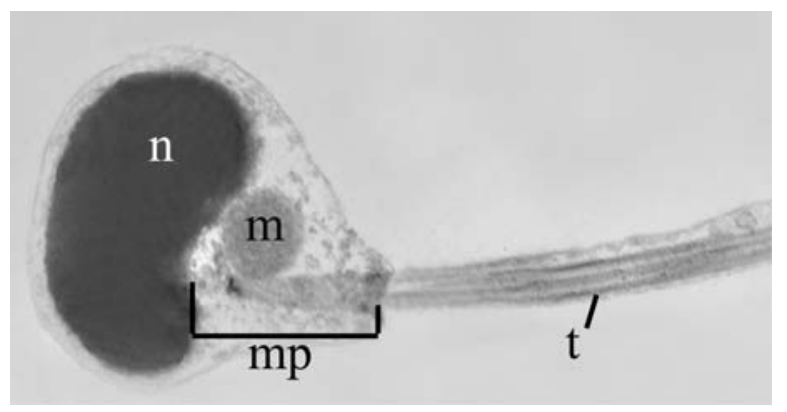

Fig. (3). Longitudinal section of P.bogaraveo spermatozoon. n, nucleus; $\mathrm{m}$, mitochondrion; $\mathrm{mp}$, midpiece; $\mathrm{t}$, tail.

\section{SEASONAL DEVELOPMENT OF GONADS}

Based upon macroscopic and microscopic observations, functional ovaries and testes of P.bogaraveo can be staged for maturity according to a five stage scale, which is reported in Table 3 and $\mathbf{4}$, respectively. The following maturity stages could be distinguished in ovaries and testes: I. immature, II. developing, III. maturing, IV. ripe, V. spent. Sexing and staging of P.bogaraveo is hardly feasible without histological examination, unless the fish are close to maturity. In fact, immature, developing and recovering spent testes may have the same aspect. For the same reason, developing and post-spawning ovaries may be undistinguishable.

\section{Ovaries}

Immature ovaries (stage I) were found in both gonochoric (F) and secondary $(\mathbf{m F})$ females until the accomplishment of the 3rd year of life, regardless of the season. During the 4th year of life, $100 \% \mathbf{F}$ and $24 \% \mathbf{~ m F}$ entered stage II (developing), while the remaining $\mathbf{m F}$ remained at

Table 2. Histological Description of Sperm Development in P.bogaraveo

\begin{tabular}{|c|c|c|}
\hline Spermatogenic Stage & Size $(\mu \mathrm{m})$ & Histological Description \\
\hline $\begin{array}{l}\text { Type A } \\
\text { spermatogonium }\end{array}$ & $15-19$ & $\begin{array}{l}\text { Clear, ovoid cells, generally found isolated. The nucleus contains a sub-central nucleolus linked to peripheral } \\
\text { chromatin masses by means of chromatin filaments. }\end{array}$ \\
\hline $\begin{array}{l}\text { Type B } \\
\text { spermatogonium }\end{array}$ & $9-10$ & $\begin{array}{l}\text { Round cells, gathered in nests of 2-16. Nucleus/cytoplasm ratio higher than type A spermatogonia. Well outlined, } \\
\text { slightly basophilic nucleus, with a single nucleolus. }\end{array}$ \\
\hline Primary spermatocyte & $6-8$ & $\begin{array}{c}\text { At early meiotic stages (pre-leptotene, leptotene), nuclear chromatin forms a tight network filling the whole } \\
\text { nucleus; subsequently (zygotene, pachitene), chromatin is condensed at one nuclear pole, in a typical "bouquet" } \\
\text { disposition; finally (diplotene, diacynesis), it formed a well-outlined ring at the periphery of the nucleus. Cytoplasm } \\
\text { barely visible. }\end{array}$ \\
\hline $\begin{array}{c}\text { Secondary } \\
\text { spermatocyte }\end{array}$ & $5-6$ & $\begin{array}{l}\text { Rarely found and hardly detectable, since the second meiotic division occurs very fast. Nuclear chromatin appears } \\
\text { very condensed. Cytoplasm barely visible. }\end{array}$ \\
\hline Spermatid & $2-3$ & $\begin{array}{l}\text { Nuclear chromatin forms discrete masses in newly formed spermatids, while it is condensed in a single mass in } \\
\text { later spermatids, so that the nucleus appears perfectly round, homogeneous, strongly basophilic. }\end{array}$ \\
\hline Spermatozoon & $1.8 \pm 0.01$ & $\begin{array}{c}\text { Ovoid, strongly basophilic head, measuring } 1.8 \pm 0.01 \mu \mathrm{m}(n=50) \text { along its major axis. Eosinophilic tail, } \\
\text { measuring } 50 \pm 4.82 \mu \mathrm{m} .\end{array}$ \\
\hline
\end{tabular}


Table 3. Macroscopic and Histological Description of Testicular Maturity Stages in Captive Pagellus bogaraveo

\begin{tabular}{|c|c|c|c|}
\hline I & Immature & Threadlike and translucent & Spermatogonia and small nests of primary spermatocytes. \\
\hline III & Maturing & Large, soft, creamy white & $\begin{array}{l}\text { All spermatogenic stages present. Spermatozoa fill the lumen of } \\
\text { seminiferous lobules. }\end{array}$ \\
\hline $\mathrm{V}$ & Spent & $\begin{array}{l}\text { Threadlike and translucent in some specimens; flabby, } \\
\text { whitish or yellowish in others }\end{array}$ & Spermatogonia and residual sperm, with no intermediate stages. \\
\hline
\end{tabular}

Table 4. Macroscopic and Histological Description of Ovarian Maturity Stages in Captive Pagellus bogaraveo

\begin{tabular}{|c|c|c|c|}
\hline I & Immature & Threadlike and translucent & $\begin{array}{l}\text { Oogonia and primary oocytes until late perinucleolus stage. } \\
\text { No evidence of previous spawning }\end{array}$ \\
\hline II & Developing & $\begin{array}{l}\text { Threadlike, thin or cylindrical in shape; pinky white, pink, } \\
\text { pale orange or yellow in colour }\end{array}$ & Oogonia and pre-vitellogenic oocytes until cortical alveolus stage II \\
\hline III & Maturing & $\begin{array}{l}\text { Large, swollen, orange coloured, with evident blood } \\
\text { vessels. } \\
\text { Oocytes visible to the naked eye }\end{array}$ & $\begin{array}{l}\text { Vitellogenic oocytes until yolk granule II stage, in addition to all previous } \\
\qquad \text { oogenic stages }\end{array}$ \\
\hline IV & Ripe & $\begin{array}{l}\text { Large, swollen, orange coloured, with evident blood } \\
\text { vessels. Eggs visible to the naked eye, and released upon } \\
\text { stripping }\end{array}$ & $\begin{array}{l}\text { Hyaline eggs present, in addition to all previous oogenic stages. } \\
\text { Post-ovulatory follicles (POF) and atretic oocytes are also visible. }\end{array}$ \\
\hline $\mathrm{V}$ & Spent & $\begin{array}{l}\text { Threadlike and translucent in some specimens; flabby, } \\
\text { whitish or yellowish in others }\end{array}$ & $\begin{array}{c}\text { Many POFs and atretic oocytes, together with pre-vitellogenic oocytes } \\
\text { until cortical alveolus stage I }\end{array}$ \\
\hline
\end{tabular}

stage I. Stage II ovaries were found from June until February. On the other hand, stage III (maturing), which corresponds to vitellogenesis, occurred fastly, so that by March, age 4, females (29.5 cm TL minimum size) were ready to spawn, with ripe ovaries (stage IV). Spent ovaries (stage V) were found in May, after which ovaries directly progressed to stage II and resumed development, leading to sexual maturity (stage III-IV) in the following FebruaryMarch. The gonosomatic index (GSI, [Gonad Weight/Total Body Weight] $\mathrm{x} 100)$ significantly increased $(\mathrm{P} \leq 0.01)$ as ovarian maturation proceeded, passing from $0.17 \pm 0.03$ at stage I to $2.74 \pm 0.91$ at stage IV.

\section{Testes}

Unlike females, males showed a marked variability in the development of gonads. In fact, testes at maturity stages from I (immature) to III (maturing) could be found throughout the winter (December-March) in specimens of all ages. The first ripe testes (stage IV) were found in April in males aged $3(28.0 \mathrm{~cm}$ TL minimum size), while spent testes with residual sperm (stage V) were found in April and May. In the following reproductive cycle, testes directly developed to stage II and reached sexual maturity (stage IV) in February-March. The GSI did not change $(0.05 \pm 0.01)$ in $1+$ and $2+$ age class, regardless of maturity stage. On the other hand, the GSI considerably increased $(0.47 \pm 0.05)$ during the spawning season in older specimens (stage IV), and decreased again to $0.20 \pm 0.01$ at stage $\mathrm{V}$.

\section{SPAWNING IN CAPTIVITY}

A captive P.bogaraveo broodstock, consisting of 21 females $(31.0 \mathrm{~cm} \pm 1.6 \mathrm{~cm} \mathrm{TL})$ and 7 males $(29.5 \pm 1.1 \mathrm{~cm}$ TL) was monitored for maturity and spawning during the reproductive season. The fish were held in outdoor tanks under a natural photoperiod and temperature $\left(13-18^{\circ} \mathrm{C}\right)$ regime, at a density of $3 \mathrm{~kg} \mathrm{~m}^{-3}$, and had been fed a mixed diet of frozen squid and commercial pellets for 2 months before the beginning of assays. Stripping and/or gonadal biopsies were performed weekly on the anaesthetized fish, from early February until end of March.

Ten out of 21 females reached maturity (stage IV) and released eggs upon stripping, 4 underwent oocyte maturation but did not ovulate, while the remaining 7 females achieved vitellogenesis (stage III) but failed to undergo oocyte maturation and ovulation. Two episodes of spontaneous spawning in the tank were recorded. The eggs $(1.18 \pm 0.002$ $\mathrm{mm}$ ) were unfertilized, and appeared perfectly spherical, translucent, with a single oil droplet $(0.025 \mathrm{~mm})$. Ovarian biopsies of mature females revealed distinct batches of oocytes at different stages of development, suggesting a group-synchronous pattern of ovarian development [7]. 
Females that did not reach maturity showed an increasing proportion of atretic oocytes in their ovaries as the reproductive season proceeded, so that by the end of March all the largest vitellogenic oocytes appeared atretic. On the other hand, in the last samplings eggs stripped from mature females appeared degenerated, swollen, and opaque, suggesting that they might be retained in the ovary, where they underwent overripening.

Five out of 7 males were running males with flowing milt from the 1st sampling on early February. Only small amounts of milt could be get (200-300 $\left.\mu \mathrm{m} \mathrm{kg}^{-1}\right)$, which was checked for density and motility, resulting in $5.5 \pm 0.02 \mathrm{x}$ $10^{9} \mathrm{ml}^{-1}$ spermatozoa concentration, $70 \%$ spermatocrit, with only $\leq 3 \%$ motile sperm. Spermiation lasted for two weeks, after which only one specimen continued to produce milt, which was extremely dense ( $86 \%$ spermatocrit) and viscous.

\section{FINAL REMARKS}

Protandrous hermaphroditism appeared to be the prevalent sexual pattern in cultured $P$. bogaraveo, although a high incidence of gonochorism occurred, as in the wild [8]. Males were most abundant in smaller size classes and reached sexual maturity at $28.0 \mathrm{~cm}$, while females predominated in the larger size classes and reached maturity at $29.5 \mathrm{~cm}$. Observations of a captive population revealed that cultured $P$. bogaraveo may reach sexual maturity earlier than in the wild. In fact, the first spawning occurred at 3 and 4 years of age, respectively, in males and females, vs. 5- 8 years in the wild [8]. The reproductive season lasted from February until April, as in the natural environment. Spontaneous spawning in tank occurred occasionally, whereas approximately $50 \%$ of females produced eggs upon stripping. The remaining $50 \%$ failed to ovulate, or even to achieve oocyte maturation, indicating an impaired reproductive functionality, as demonstrated also by a high incidence of oocyte atresia. This is the most common reproductive dysfunction in captive fish, and may diminish after many generations of fish are produced in culture conditions [9]. Captivity appeared to affect also males, which produced a small quantity of highly viscous milt, containing only $3 \%$ motile spermatozoa. For these reasons, conditioning of broodstock by hormonal stimulation would probably be required to achieve a full control of reproduction in captivity.

\section{REFERENCES}

[1] Zohar Y, Mylonas CC. Endocrine manipulations of spawning in cultured fish: from hormones to genes. Aquaculture 2001; 197: 99136.

[2] Peleteiro JB, Olmedo M, Alvarez-Blázquez B. Culture of Pagellus bogaraveo: Present knowledge, problems and perspectives. Cah Options Médit 2000; 47: 141-51.

[3] Greco S, Cavaliere A, Lo Paro G, Manganaro A, Sturniolo G. Effetti di diete bilanciate nell'allevamento intensivo di Pagellus bogaraveo. Oebalia 1989; XV-2: 637-44.

[4] Micale V, Patti F. Accrescimento ed efficienza di conversione in Pagellus bogaraveo sottoposto a differenti regimi fotoperiodici. Biol Mar Medit 1997; 4(1): 330-1.

[5] Micale V, Maricchiolo G, Genovese L. The reproductive biology of blackspot sea bream Pagellus bogaraveo in captivity: 1. Gonadal development, maturation and hermaphroditism. J Appl Ichthyol 2002; 18: 172-6.

[6] Maricchiolo G, Laurà R, Genovese L, Guerrera MC, Micale V, Muglia U. Fine structure of spermatozoa in the blackspot sea bream Pagellus bogaraveo (Brünnich, 1768) with some considerations about the centriolar complex. Tissue Cell 2010; 42(2): 88-96.

[7] Wallace RA, Selman K. Cellular and dynamic aspects of oocyte growth in Teleosts. Am Zool 1981; 21: 325-43.

[8] Krug HM. The azorean blackspot seabream, Pagellus bogaraveo (Brünnich, 1768) (Teleostei, Sparidae). Reproductive cycle, hermaphroditism, maturity and fecundity. Cybium 1990; 14(2): 151-9.

[9] Mylonas CC, Zohar Y. Promoting oocyte maturation, ovulation and spawning in farmed fish. In: Babin PJ, Cerdà J, Lubzens E, Eds. The Fish Oocyte: From Basic Studies to Biotechnological Applications. Dordrecht: Springer 2007; pp. 437-74. 